\title{
REGIONAL DIFFERENCES IN THE LEVEL OF TOURISM DEVELOPMENT IN THE RUSSIAN FEDERATION
}

\author{
Elena G. KROPINOVA* \\ Immanuel Kant Baltic Federal University, Institute of Econonics, \\ Management and Tourism, 14 A. Nevskogo St, Kaliningrad, 236016, Russia, e-mail: kropinova2@mail.ru
}

Tatiana Y. KUZNETSOVA

Immanuel Kant Baltic Federal University, Institute for Regional Studies,

14 A. Nevskogo St, Kaliningrad, 236016, Russia, e-mail: tikuznetsova@kantiana.ru

\section{Gennady M. FEDOROV}

Immanuel Kant Baltic Federal University, Institute for Regional Studies,

14 A. Nevskogo St, Kaliningrad, 236016, Russia, e-mail: Gfedorov@ kantiana.ru

Citation: Kropinova, E.G., Kuznetsova, T.Y., \& Fedorov, G.M. (2020). REGIONAL DIFFERENCES IN THE LEVEL OF TOURISM DEVELOPMENT IN THE RUSSIAN FEDERATION. GeoJournal of Tourism and Geosites, 32(4), 1330-1336. https://doi.org/10.30892/gtg.32421-577

\begin{abstract}
This article presents an analysis of the level of tourism development across the Russian Federation. The study explores Russian regions by considering the key characteristics of tourism: the number of accommodation facilities, international visitors staying in accommodation facilities, the number of people employed in tourism and hospitality, and the value added created by these sectors of economy. An aggregate index is used to assess levels of tourism and recreation development and compare administrative units on this measure. An original methodology is employed to track shifts in Russian tourism, identify regions specialising in tourism, and forecast tourism development at a regional level.
\end{abstract}

Key words: tourism, value added, tourism potential, tourism regional typology, Russian regions, tourism specialisation, regional economy

$* \quad * \quad * \quad * \quad * * *$

\section{INTRODUCTION}

In the $21^{\text {st }}$ century, tourism in Russia has experienced considerable growth. Tourism infrastructure has been rapidly developing: for example, as far as accommodation facilities are concerned, from 8,581 units in 2002 to 28,302 in 2019 (Rosstat, 2019a). The total number of bed-places in accommodation establishments increased from 1,097 thous. to 2,946 thous. over that period (Rosstat, $2019 \mathrm{~b}$ ), or to 17 beds per 1,000 residents. This ratio is similar to that in EU countries with moderately developed tourism (21), Romania (17), and Serbia (16). The EU's highest (273) is observed in Croatia - a country specialising in tourism (Eurostat, 2019).

Tourism in Russia has the following typical features. In terms of arrivals, domestic tourism far outstrips international tourism. In 2019 , the number of check-ins at various accommodation establishments showed year-on-year growth of $0.6 \%$ - from 70,106 to 70,558 thousand people. Although the number of Russian tourists increased from 59,952 to 60,429 thous. people, that of international tourists fell from 10,154 thous. to 10,129 thous. The percentage of the latter declined from 14.47\% to 14.35\% (Rosstat, 2019c, 2019d). The Federal Agency for Tourism of the Russian Federation estimates the number of international arrivals as 2.4 times that of check-ins. This situation owes to a developed peer-to-peer accommodation sector, which neither keeps guest records nor registers international tourists with the migration services (registration is not required if a foreign national stays in the country for fewer than seven days). The number of people using peer-topeer accommodation services is calculated using sample survey results, which are extrapolated to the total number of visitors.

In 2018, the number of arrivals was estimated at 24,551 thousand people; in 2019, at 24,419 (Russia tourism, 2018; 2019). On the number of international tourists, which was very insignificant in the Soviet period, Russia ranks high $\left(16^{\text {th }}\right)$ in the world.

Outbound tourism numbers are comparable to those of domestic tourism. In 2018, 41,964 thousand trips were taken; in 2019, 45,300 thousand. Former Soviet republics accounted for 38\% of the travel; Turkey, Finland and China, for 28\%; Germany, Italy, Thailand, Poland and Spain, for 13\% (Rosstat, 2019e). Russian ranks sixth in the world for outbound tourism (according to the Knoema World Atlas database, which treats Hong Kong as a separate entity) (World Data Atlas, 2019). A few Russian regions boast a large number of visitors: $41 \%$ of those who stayed outside their place of residence in 2019 opted for five (out of 85) Russian regions: the Krasnodar region (the Black Sea coast), Moscow and the Moscow region, St Petersburg and the Leningrad region. Moscow and St Petersburg account for 68\% of international arrivals.

\section{METHODOLOGY}

Spatial differences in tourism development across Russia will be analysed at a regional level (Figure 1), using available statistics, particularly the information on:

- the number of bed-places in accommodation establishments;

- the number of people employed in the tourism and hospitality industry;

- the number of people accommodated in accommodation establishments;

- the value added by accommodation establishments and the food service industry;

- the number of international visitors staying in accommodation establishments.

Tourism development in Russia as seen by national and international researchers

Russia as a destination

Most publications deal with general reviews of Russia as a destination, and they are in effect country studies. For example, Pshtyka and

\footnotetext{
* Corresponding author
} 
Tolkach (2014) in Springer's Encyclopedia of Tourism limit the information to widely known facts, such as: 'The most popular destinations are Moscow and Saint Petersburg. Major routes in Russia include a journey around the Golden Ring of ancient cities, Volga River cruises, and Trans-Siberian Railway journeys. Other important destinations include Kazan (the capital of Tatarstan portraying a mix of Russian, Orthodox and Muslim Tatar cultures), Sochi (the most popular Black Sea resort and the site of the 2014 Winter Olympics), and Northern Caucasus (which contains popular ski resorts). The most famous natural destinations include Lake Baikal, the deepest lake in the world, Kamchatka with its volcanoes and geysers, Karelia with its lakes and granite rocks, the Altai Mountains, and the steppes of Tyva'.

In their analysis of tourism development in Russia, Givental et al stress that, since the dissolution of the Soviet Union, many regional authorities have promoted national resorts by touting local resources such as thermal springs, lakes, rivers, and mountains. A lack of investment in tourism infrastructure, insufficient support from local authorities, and poor promotion hamper tourism development. Another obstacle is residents' concerns about the rising number of visitors (Givental et al. 2019).

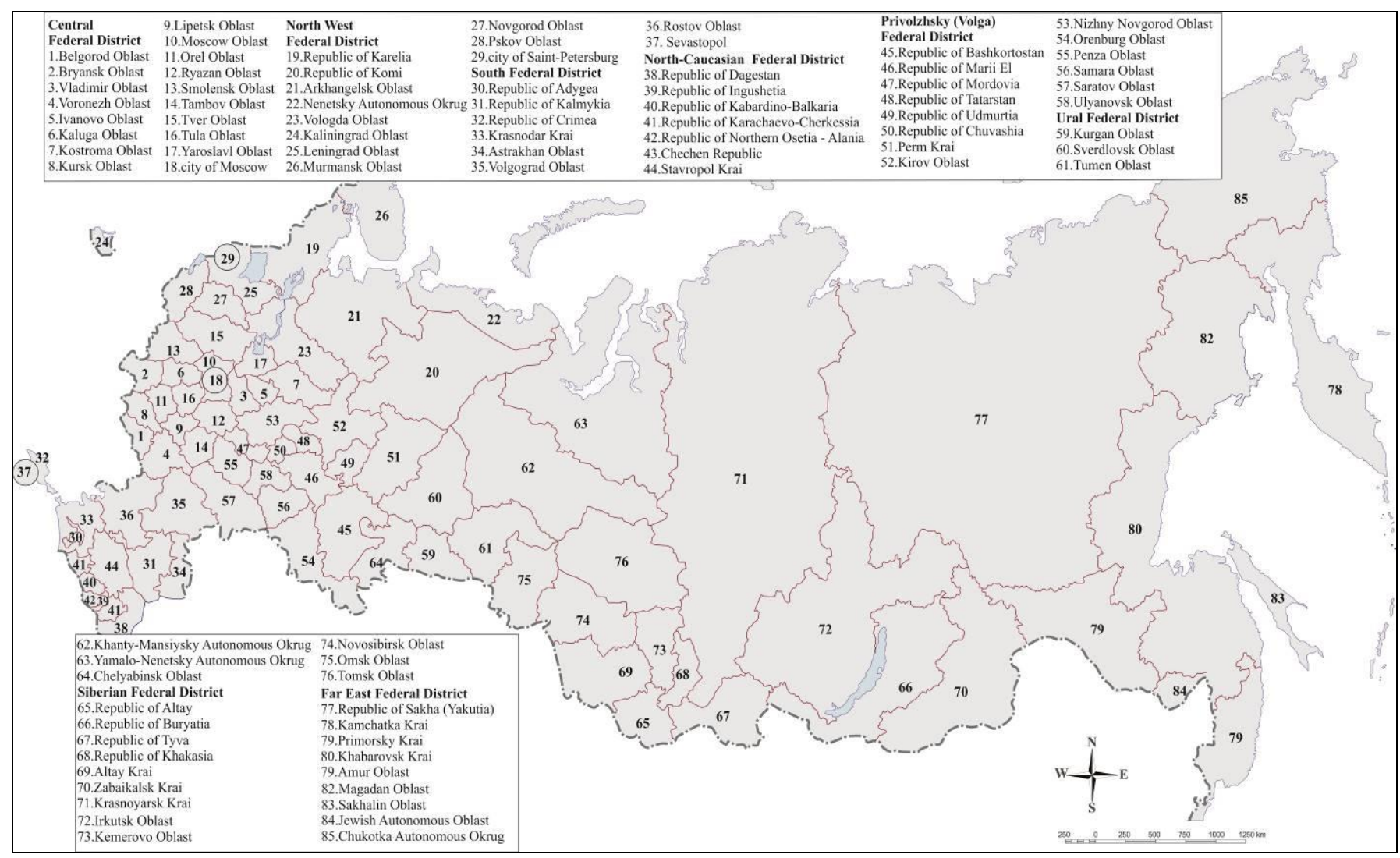

Figure 1. Russian regions

A. Aleksandrova identified five main types of tourism of countries used different socio-economic indicators and characteristics of tourism sector. As a result Russia was put into the third group of countries, which "includes moderately developed countries of the periphery of the world's touristic space, with a polyfunctional system of international tourism in the stage of transformation and formation of a civilized travel market, a profitable relationship of the price and quality of touristic services, and the intraregional orientation of tourist flows" (Aleksandrova, 2016). That means that the country does not fulfil its tourism potential, mostly due due to the fact that development had largely an extensive character and, until very recently, was proceeding mainly through a direct growth of the volumes of inbound and outbound tourist flows. Most researchers emphasise that tourism can boost national socio-economic development. This is especially true for the border regions that offer joint tourism products (Katrovsky et al., 2017; Manakov and Golomidova, 2018; Stepanova and Shlapeko, 2018; Deac et al., 2019; Spiriajevas, 2019; Azhayev et al., 2020; Ilies et al., 2020;) Kropinova, 2020 and impact the regional innovation growth (Gorochnaya et al., 2020).

Lukhovskaya et al (2019) consider various tourism development models that appeared before 2017 and make explicit comparisons between levels of inbound, domestic, and outbound tourism development as well as the economics of the industry. It is concluded that Russian tourism services imports have been growing since 2014 when the exports plummeted. The dynamics of indicators is still so small that it cannot be called a significant component of the innovative development of Russia. A special role was played by the second wave of the crisis and sanctions against Russia. Strategic decisions on domestic tourism development in Russia should be modelled based on the management of cultural potential - a system of measures for including elements of this potential in the tourism product and making effective use of it whilst preserving the balance between the national cultural tradition and the radical renewal of regional cultural potentials.

In Tourism Leadership in Russia: Regional Capacity Estimation, authors analyse current trends in tourism development in Russia (Murtuzalieva et al., 2018). They argue that despite the enormous tourism potential and many natural and artificial wonders and beauties, Russia is still struggling to boost inbound tourism and make it more attractive to international visitors. In this study, the authors explore why some Russian regions are not attractive as destinations and propose a methodology for evaluating regional potentials. The methodology was tested on the North Caucasus Federal District (NCFD). The efficient functioning of available resources requires effective management of a region's potential. Evaluating regional potential makes it possible to locate hidden reserves of a territory. This evaluation should rely on a system of measures, which have been divided by researchers into five groups: economic, social, environmental, demographic and resource availability- and use-related. There are no highly developed areas in the NCFD: none of its regions has a score of three. The Republic of Dagestan, the Chechen Republic, and the Stavropol Krai (region) fall in the top category in terms of labour and natural resources and investment opportunities. The other regions are classified as having poorly developed regional opportunities (Murtuzalieva et al., 2018). 
Common reasons for the low competitiveness of some Russian regions include insufficient public and private investment in tourism and lack of experience in public-private partnerships. Rogach et al write that the tourism potential of Russian regions remains untapped because a systemic end-to-end cycle of production and sales of goods and services has not been created, integration of science, education, and business has not taken place, and the problems of industrial and agricultural areas have not been solved (Shomanova et al., 2017; Rogach et al., 2020; Suleimenov et al., 2020).

\section{Intra-regional differences and tourism development in Russia}

Regional differences in tourism across Russia as well as tourism zoning have been extensively studied in the 1970-80s. The Russian school of social and economic zoning developed a comprehensive theoretical framework for region-building, which made it possible to identify regions specialising in tourism and recreation. Recreational zoning was developing from the second half of the 1970s when there was increased attention to research in the services sector, including rapidly developing tourism and recreation.

A major contribution to the theory and practice of recreational zoning was the research of leading Russian geographers working on the topic in 1960s-1980s (Zorin, 1969; Preobrazhensky, 1975; Vedenin, 1982; Mironenko and Bocharova, 1986; Mironenko et al., 1989). In our opinion, the four zones and 20 districts distinguished by the founder of recreation zoning, Preobrazhensky (1975), and his followers constitute a hierarchy with four first-level zones comprising 20 subzones specialising in tourism and recreation. Although the number of zones and subzones changed later, the approach to identifying them remained unchanged. In a market economy, this approach not only is important as a research tool but also can be used to produce recommendations for tourism businesses as regards creating tourism and recreation facilities. Many Russian researchers share our opinion. Pogodina and Matveevskaya (2017) note that the methods used earlier in recreational geography have been applied in the geography of tourism to regional systems of tourism planning. Of particular interest here is their study conducted in the European part of Russia and published in the multi-authored monograph The Geography of Tourism of Central and Eastern European Countries edited by Widawski and Wyrzykowski (2017). Although the materials used in the article, including cartographic ones, date back to 2010-2011, this research can aid in analysing the situation within a ten-year interval.

\section{RESULTS AND DISCUSSION: LEVELS OF TOURISM DEVELOPMENT IN THE RUSSIAN FEDERATION}

\section{Spatial variations in tourism development measures}

The results of this study and key measures of tourism development were used to compute cartograms of levels of tourism development in Russian regions according to the key indicators of tourism development. The cartograms (Figure 2-6) show the measures from the Methodology section as a per 1,000 population rate. Each indicates the state of tourism and related sectors since traditional accommodation establishments provide services to both tourists and other visitors, and restaurants are frequented by locals as well as non-locals. Moreover, some tourists prefer peer-to-peer accommodations or staying with family and friends. Not all of them eat out. To discriminate between these groups one has to conduct costly surveys, which nevertheless do not fully guarantee the accuracy of data. Thus, we will use five indicators tracked by national statistics services. We believe that, combined, they provide a sufficiently precise picture of tourism development in regions.

\section{Bed-places in traditional accommodations}

We will dwell upon the evaluation of bed-places available from traditional accommodation providers per 1,000 population since this measure is both an indicator of demand and a factor in destination attractiveness.

The number of beds per 1,000 population ranges from 1.1 in the Republic of Ingushetia (North Caucasus) to 81.3 in the Krasnodar Krai (region at the Black Sea coast in the Caucasus). Most Russian seaside resorts are located in the latter region, which accounts for 457,000 beds, or $19 \%$ of the national total. The Krasnodar Krai is Europe's renowned beach destination. Its highlight and largest resort is Sochi. A nearby location, Krasnaya Polyana, is home to Russia's biggest ski resort. In 2014, Sochi hosted the 2014 Winter Olympics. Only nine European countries have a higher ratio of beds per 1,000 population than the Krasnodar Krai does.

Another region where this measure is high is the Republic of Altai, whose major tourist attractions are unique mountain landscapes. Its ratio is explained, however, by the republic's small population rather than the abundance of beds. Natural sites are an equally important factor in the tourist attractiveness of the Republic of Karelia, the Kamchatka Krai and the Chukotka Autonomous Okrug, all of which are sparsely populated and thus have a high ratio of beds per 1,000 residents (Figure 2).

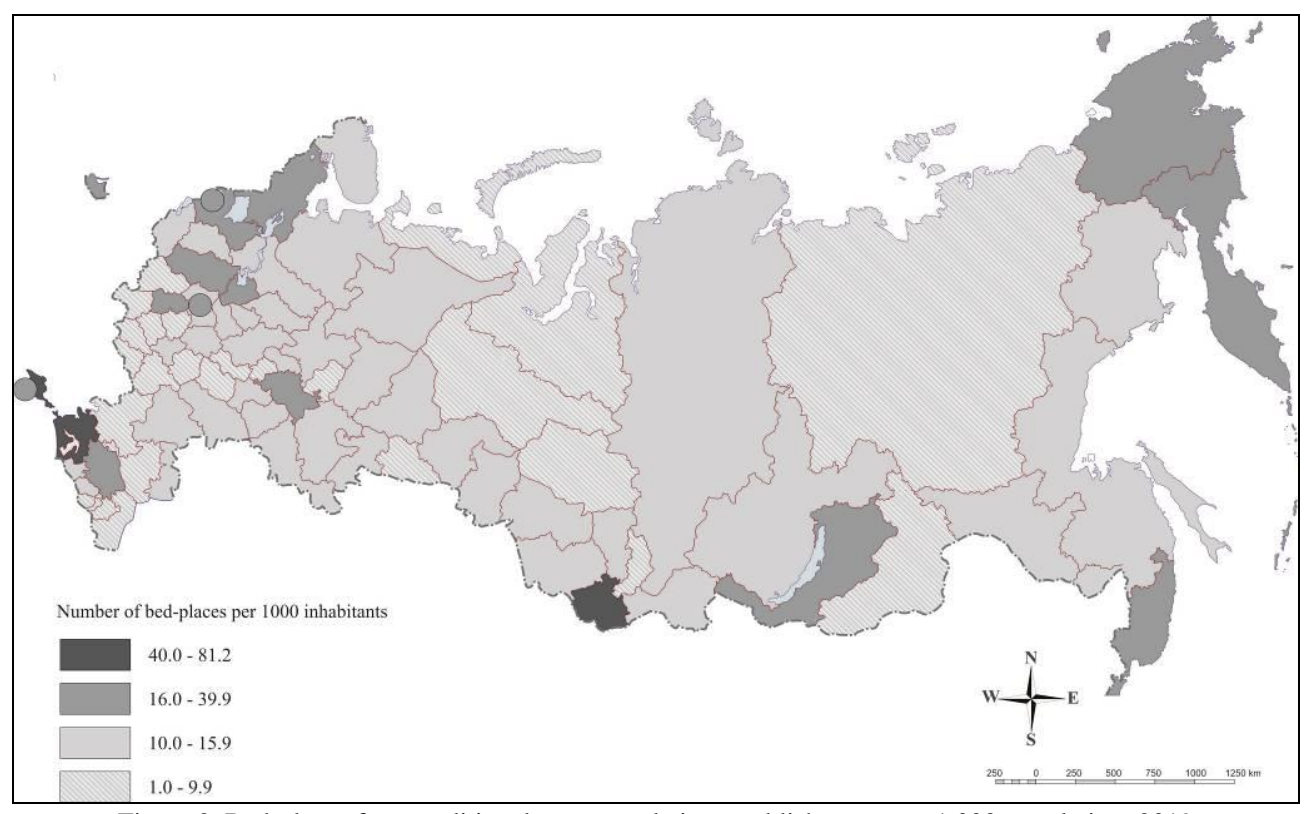

Figure 2. Bed-places from traditional accommodation establishments per 1,000 population, 2019

(Source: Prepared by the authors based on data from https://fedstat.ru/indicator/31583) 
Among regions with a substantial number of beds are the megalocities of Moscow and St Petersburg as well as the Kaluga, Tver, and Yaroslavl Oblasti (regions), which border on Moscow, and the Leningrad Oblast, which borders on St. Petersburg. These four re gions are Muscovites' and St Petersburgers' favourite vacation destinations. They are home to cultural and historical sites that attract Russian and international visitors. Popular cultural, historical, and natural sites are located in the middle reaches of the Volga in the Republic of Tatarstan, whereas wellness and health resorts are found in the Stavropol Krai and the North Caucasus. Strong inbound tourism and the nation's leading resorts translate into a considerable number of hotel beds in border areas such as the Repub lic of Buryatia, the Primorsky Krai and the Kaliningrad Oblast. A low number of beds (ten or fewer per 1,000 population) is typical for territories in the north (the Republic of Yakutia, the Tomsk Oblast, Nenets, and Khanty-Mansiysk, Autonomous Okruga/regions and the Yamalo-Nenets Autonomous Okrug) and east of the country (Republic of Khakassia, Transbaikal Krai and Kurgan Oblast).

The situation is pretty much the same along the borders with Belarus and Ukraine (the Smolensk, Bryansk, Kursk, Belgorod, Voronezh, and Rostov Oblasti/regions, from north to south) and in the neighbouring Orel, Tambov, and Tula Oblasti/regions. Republics of Mordovia, Chuvashia, Udmurtia, and the Penza Oblast are no different in this respect. The number of hotel beds is rather low in the southern republics of European Russia - Adygeya, Dagestan, North Ossetia-Alania, Ingushetia, and the Chechen Republic. An almost uninterrupted belt from the Murmansk, Pskov, Astrakhan, and Volgograd Oblasti/regions in the west to the Magadan and Sakhalin Oblasti/regions in the east performs somewhat below the national average. The same can be said of the republics of Kabardino-Balkaria and Karachay-Cherkessia in the North Caucasus, which are known for their ski and spa resorts.

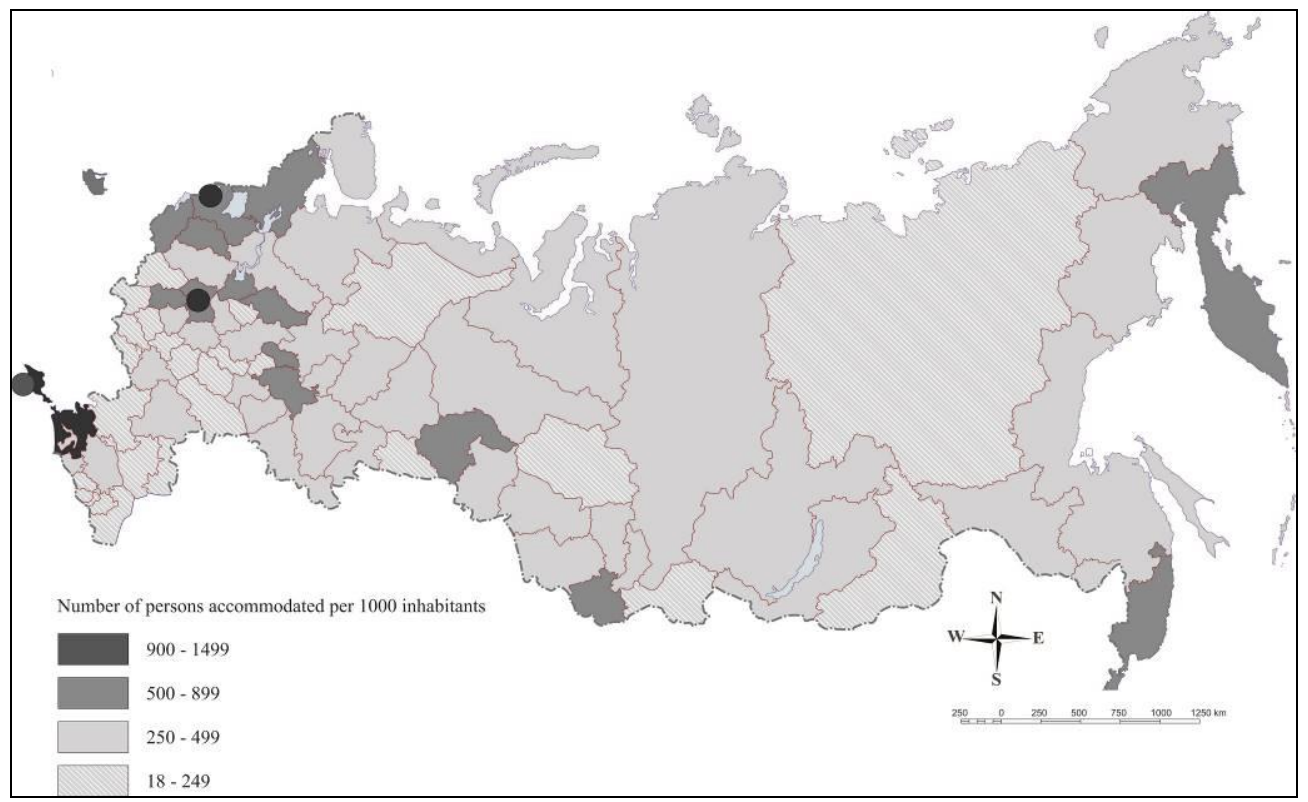

Figure 3. The number of persons accommodated in traditional accommodation establishments per 1,000 population

(Source: Prepared by the authors based on data from fedstat.ru/indicator/31560)

\section{The number of people accommodated in traditional accommodations}

The number of people staying in traditional accommodations closely correlates with the number of available bed-places (Spearman's correlation coefficient is 0.75 ), yet they do not exactly coincide, as Figs. 2 and 3 show.

The highest ratio of people staying in traditional accommodations per 1,000 population as well as that of beds is observed on the Black Sea coast, in Moscow, and St Petersburg. They are followed by Russia's northwestern territories bordering on the EU (the Republic of Karelia, the Kaliningrad, Leningrad, and Pskov Oblasti/regions, and the adjacent Novgorod Oblast), the Kaluga, Yaroslavl, and Kostroma Oblasti/regions near Moscow, and the Republic of Tatarstan. The Tyumen Oblast (where oil and gas workers from the Khanty-Mansiysk and Yamalo-Nenets Autonomous Okruga/regions stay at hotels), the scenic Republic of Altai and Kamchatka Krai, and the Primorsky Krai, which is often visited by inbound tourists, stand out in the east of the country.

The number of people employed in the tourism and hospitality industry. The regional distribution of people employed in the tourism and hospitality industry (Figure 4) differs substantially from the patterns shown in Figures 2 and 3 because it takes into account not only accommodations but also places to eat, which are visited by locals. Spearman's correlation coefficient between people employed in the hospitality industry and the number of bed-places at traditional accommodation establishments is 0.47 ; that between the number of people employed in the hospitality industry and the number of people staying in traditional accommodations, 0.56 . In all the three cases, high figures are observed in Moscow, St Petersburg, and the Krasnodar Krai, followed by the Republics of Karelia and Tatarstan, and the Primorsky Krai, Kaliningrad, and Kaluga Oblasti/regions. The lowest-performing territories are:

- the Republic of Sakha (Yakutia) in the far East;

- the Transbaikal Krai in Siberia at the Chinese border;

- the South Ural region of Kurgan at the border with Kazakhstan;

the Republics of Mordovia and Chuvashia on the banks of the Volga;

- the Republics of Dagestan, Ingushetia, and Chechnya in the North Caucasus;

- the western border regions of Smolensk, Kursk, Belgorod, and Rostov, and the adjacent Lipetsk and Tambov Oblasti/ regions.

\section{The value added by hotels and food service organisations}

Just as the previous measure, the value added is considered as created by both hotels and food service organisations, which do not cater exclusively to tourists. Besides, it correlates with regional prices, which are higher in the north and east of the country and relatively low in the south of European Russia. The correlation coefficient between this measure and the number of beds per 1,000 population is only 0.44 . The highest value added per 1,000 population (Figure 5) is created in the north in the sparsely populated gas- 
producing Yamalo-Nenets Autonomous Okrug/region (17,000 roubles in 2018). The Krasnodar Krai ranks second with 14,6 thousand roubles and Moscow third with 12,8 thousand roubles. The national average is 5,8 thousand roubles. The worst performing region is Ingushetia with 338 roubles. Figure 5 shows the regional differences.

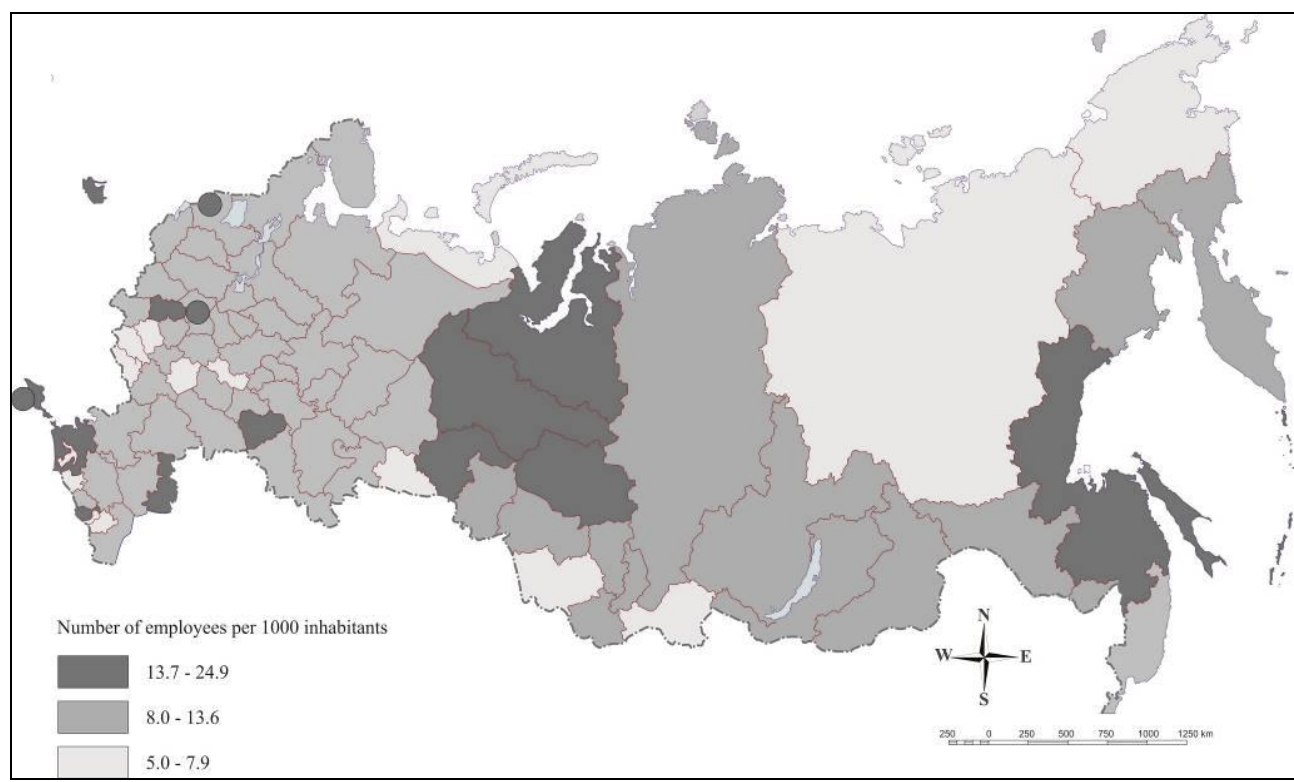

Figure 4. The average annual number of people employed in the tourism and hospitality industry per 1,000 population, 2018 (Source: Prepared by the authors based on data from https://fedstat.ru/indicator/58994)

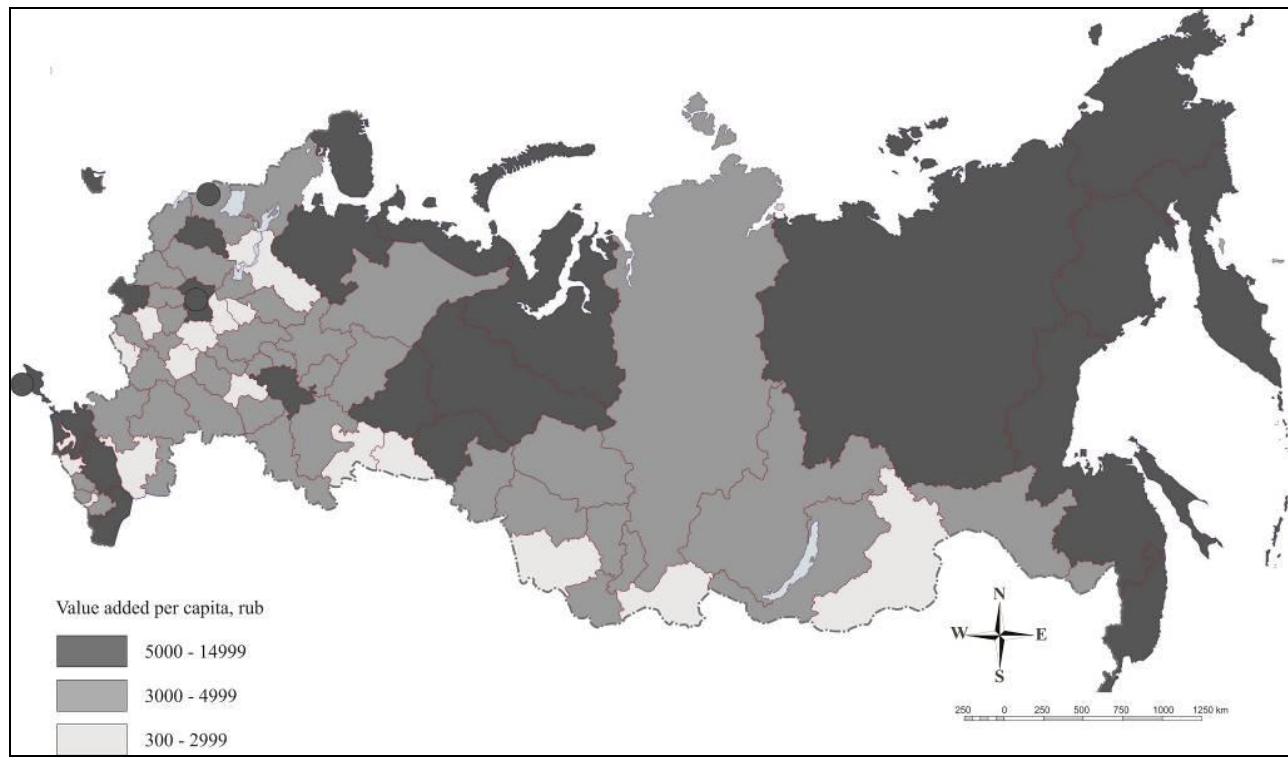

Figure 5. The value added by hotels and food service organisations per 1,000 population, 2018

(Source: Prepared by the authors based on data from https://fedstat.ru/indicator/42928 (Gross regional product per capita.

Unified Interdepartmental Statistical Information System); https://www.fedstat.ru/indicator/59450 (Composition of gross regional product. OKVED 2)

\section{The number of international visitors staying in traditional accommodations}

Over two-thirds of international visitors visit only two cities - Moscow (45\%) and St Petersburg (24\%). The Moscow region accounts for $5.6 \%$ of international visitors; the Primorsky Krai, Krasnodar Krai, and Irkutsk Oblast, for 2-3\% each; the Sverdlovsk Oblast, for 1\%. The other regions welcome even fewer tourists from abroad. Figure 6 shows the international visitors per capita ratio. Moscow, its neighbouring regions, where the historical cities of the so-called Golden Ring of Russia are located, St Petersburg, the regions bordering on the EU, and the adjacent Novgorod Oblast with its slew of cultural attractions perform the best on this measure. In the east, the front runners are the Primorsky Krai and Amur Oblast (they border on China - the home country of most international visitors coming there), the Kamchatka Krai famous for its geysers and volcanoes, and the Republic of Buryatia and the Irkutsk Oblast abutting Lake Baikal.

\section{An aggregate index of spatial differences in the level of tourism development in Russia}

Based on their summed up ranks on the five measures, we divided Russian regions into five groups (Figure 7).

As Figure 7 shows, the leaders are Moscow and St Petersburg, major urban tourism destinations, and the Black Sea coast, which offers a lot when it comes to health and beach tourism. At the top of the index are the Moscow Oblast and Kaluga Oblast, which are located near Moscow, Republic of Karelia and Kaliningrad Oblast, which are on the north-west of Russia, the Republic of Tatarstan on the banks of the Volga, and the Primorsky Krai, Kamchatka Krai, and Sakhalin Oblast on the Far East. A number of regions located near Moscow and St. Petersburg demonstrate the indicators as above average. That could be explained by the fact that many residents of the two megalopolises as well as residents of other regions of the country and foreigners visit this destinations thanks to the numerous cultural and historical monuments located here. Among other territories that perform well on this measure is the Stavropol Krai, which abounds with wellness 
establishments. The same holds for the Samara, Sverdlovsk, and Tyumen Oblasti/regions. The Republics of Altai and Buryatia and the Khabarovsk and Magadan Oblasti/regions perform above average. The above assessment of tourism development in Russian regions is rather similar to the ranking developed by the Ministry of Culture of the Russian Federation. The evaluation was prepared in collaboration with Moscow State University and the expert and business communities. When developing the ranking, mechanisms for tourism support, promotion campaigns, and other regional factors were taken into account along with statistical data. The correlation coefficient between the rankings of Russian regions on these two ratings is 0.60. For instance, Moscow, St Petersburg, the Krasnodar Krai, and the Republic of Tatarstan rank first to fourth respectively on the ranking by the Ministry of Culture (Ministry of Culture of the Russian Federation, 2020). The same territories are at the top of our ranking as well. The most poorly tourism performing regions (ranking $82^{\text {nd }}-85^{\text {th }}$ ) are the Transbaikal Krai, Kurgan Oblast, Jewish Autonomous Oblast, and Chukotka Autonomous Okrug. The first two regions from this list in the assessment presented in this article are also included in the group with low indicators. However, the last two regions were in the group with average indicators.

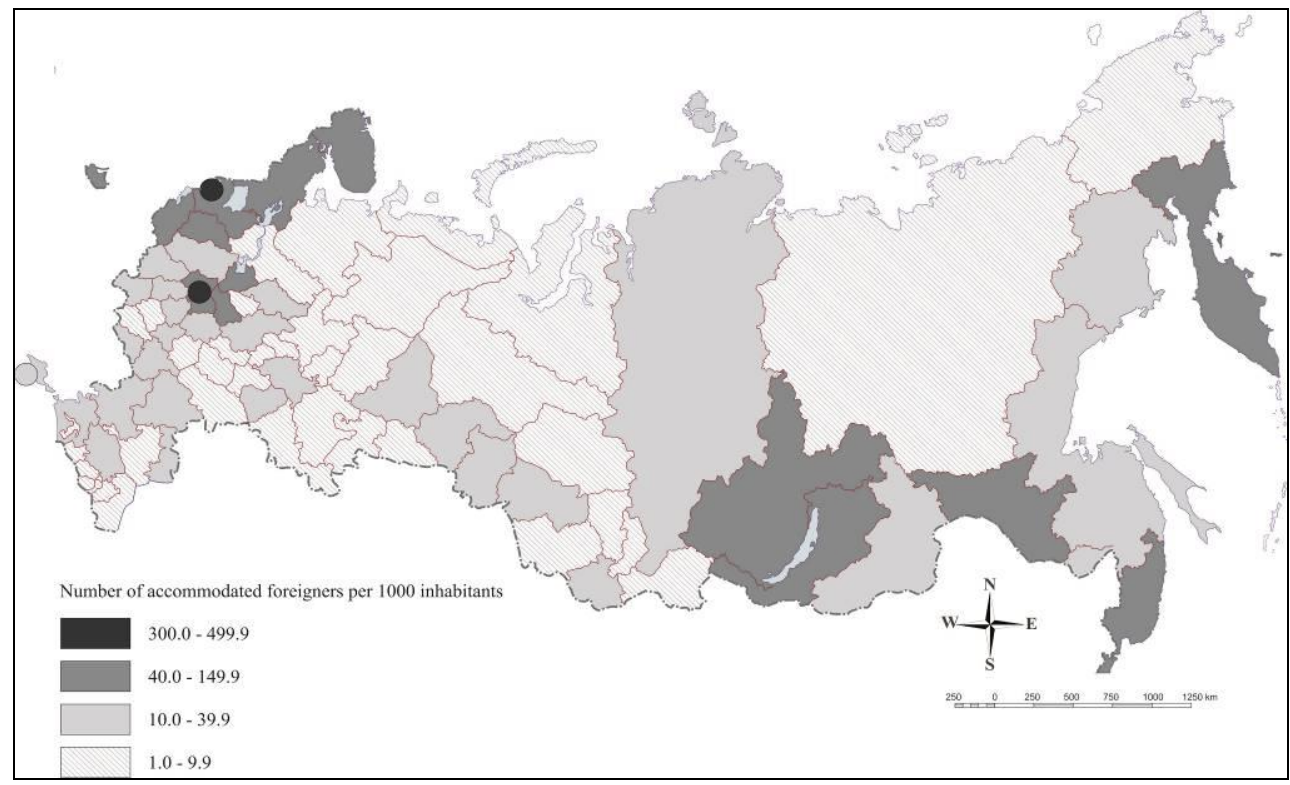

Figure 6. The number of international visitors staying in traditional accommodation per 1,000 population, 2019 (Source: Prepared by the authors based on data from https://fedstat.ru/indicator/44042)

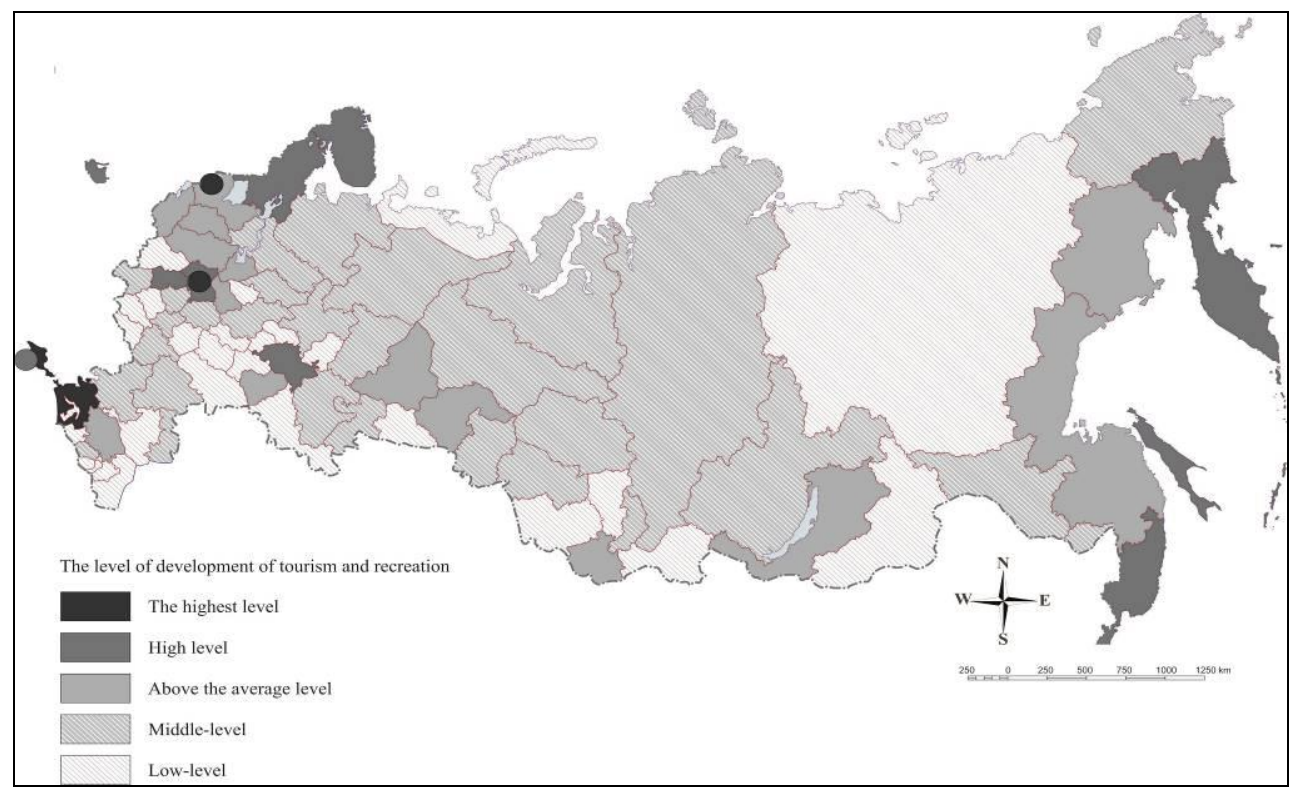

Figure 7. An assessment of the tourism performance of Russian regions, based on the five measures

(Source: Prepared by the authors based on data from Figures 2-6; The tourism index of Russian regions. Ministry of Culture of the Russian Federation URL: https://www.mkrf.ru/press/news/reyting-subektov-rossiyskoy-federatsii-po-razvitiyu20171006160552/)

\section{CONCLUSION}

Tourism is an economic development priority for many Russian regions. The undisputed leaders are the capitals - Moscow and St Petersburg (cognitive domestic and inbound tourism) - and the Black Sea coast (beach and health tourism). Among the front runners are the Republics of Tatarstan and Karelia, the Primorsky Krai, Moscow, Kaluga, Murmansk, and Kaliningrad Oblasti/regions. Many regions that are rich in natural beauty lack the necessary infrastructure for effective tourism development.

In 2010-2019, Russia and its regions witnessed significant advances in tourism infrastructure. Overall, the number of hotel bed-places increased by $98 \%$ across the country. By 2019, this number more than doubled in many regions with a high, average, and low level of tourism development, as compared to 2010. The most substantial change - a threefold rise - was observed in Moscow. St Petersburg, the Republics of Altai and Tatarstan, the Krasnodar Krai, Khabarovsk, Kaliningrad, Kaluga, and Yaroslavl Oblasti/regions, which are popular destinations, saw the number of hotel beds increase more than twofold. The growth, however, was similarly high in some regions with an 
average (the Astrakhan, Voronezh, and Chukotka Oblasti/regions) and low level of tourism development (the Republics of Adygea, Dagestan, Ingushetia, Chechnya, and Tyva, the Belgorod, Kursk, Orel, and Penza Oblasti/regions). Traditional destinations are rapidly developing and new tourism centres are emerging. Tourism is playing a growing role in the Russian economy.

To ensure the comprehensive development of domestic and inbound tourism, the Tourism Development Strategy for the Russian Federation 2035 was designed and approved. Its goals are favourable conditions for the development and promotion of high-quality tourism products, competitiveness in the domestic and global markets, a stronger community role of tourism, and the availability of tourism, recreation, and wellness services for all residents of the Russian Federation (Strategia razvitia turizma v Rossijskoy Federazii do 2035, 2019). The strategy holds that its successful implementation will result in the value added by tourism increase at the rate of national economic growth as early as 2025 . Special attention will be paid to identifying priority territories and unlocking their potential. The approach proposed in this study may aid in devising strategies and spatial planning documents as well as providing necessary information on tourism development for Russian and international investors.

\section{REFERENCES}

Aleksandrova, A.Y. (2016). Typology of countries of the world according to the development level of international tourism. Geography and Natural Resources, 37, 18-25. https://doi.org/10.1134/S1875372816010030

Azhayev G., Esimova D., Sonko S.M., Safarov R., Shomanova Zh. \& Sambou A. (2020). Geoecological environmental evaluation of Pavlodar region of the Republic of Kazakhstan as a factor of perspectives for touristic activity. GeoJournal of Tourism and Geosites, 28(1), 104-113. https://doi.org/10.30892/gtg.28108-455

Deac, L.A., Gozner, M. \& Sambou A. (2019). Ethnographic museums in the rural areas of Crişana region, Romania - keepers of local heritage, tradition and lifestyle. GeoJournal of Tourism and Geosites, 27(4), 1251-1260. http://doi.10.30892/gtg.27411-430

Givental, E., Stepanov, A.V., Ilyushkina, M.Y. et al. (2019).The Post-Industrial Landscapes of Central Urals, Russia: Heritage Value, Tourist Potential, and Unrealized Opportunities. Regional Research of Russia, 9, 193-203 https://doi.org/10.1134/S2079970519020035

Gorochnaya, V.V., Mikhaylov, A.S., Mikhaylova, A.A., \& Plotnikova, A.P. (2020). Tourism clusters and innovation security: Dialectics in the western border regions of Russia. Geojournal of Tourism and Geosites, 28 (1), 127-139. https://doi.org/10.30892/gtg.28110-457

Ilieș, D.C., Caciora, T., Herman, G.V., Ilieș, A., Ropa, M., \& Baias, Ș. (2020). Geohazards affecting cultural heritage monuments. A complex case study from Romania. GeoJournal of Tourism and Geosites, 31(3), 1103-1112. https://doi.org/10.30892/gtg.31323-546

Katrovsky, A.P., Kovalev, Yu.P., Mazhar, L.Yu., \& Shcherbakova, S.A. (2017). Tourism in border regions: theoretical aspects of a geographical study. Baltic Region, 9 (1), 81-90. doi: https://doi.org/10.5922/2079-8555-2017-1-7

Kropinova, E.G. (2020). The Role of Tourism in Cross-Border Region Formation in the Baltic Region. In: Fedorov G., Druzhinin A., Golubeva E., Subetto D., Palmowski T. (eds) Baltic Region-The Region of Cooperation. Springer Proceedings in Earth and Environmental Sciences. Springer, Cham https://doi.org/10.1007/978-3-030-14519-4_10 https://link.springer.com/chapter/10.1007/978-3-030-14519-4_10

Lukhovskaya, O.K., Arefieva, N.T., Vostrova, A.P., Fomina, N.V. \& Kireeva M.M. (2019). Diagnostics of Russian Tourism's Innovative and Economic Development in the Service Sphere. In: Popkova E. (eds) Ubiquitous Computing and the Internet of Things: Prerequisites for the Development of ICT. Studies in Computational Intelligence, vol 826. Springer, Cham. https://doi.org/10.1007/978-3-030-13397-9_80

Manakov, A., \& Golomidova, E. (2018). Estimating the development of the Latvian - Estonian - Russian transboundary tourism and recreation region. Baltic Region, 10(1), 130-141. https://doi.org/10.5922/2079-8555-2018-1-8

Mironenko, N.S. \& Tverdokhebov, I.T. (1981). Recreazionnaja geographija [Recreation geography]. M.: Izd-vo MGU, 207 pp. (in Russian).

Mironenko, N.S., Pirozhnik, I.I. \& Tverdokhebov, I.T. (1989). Teoreticheskie osnovy recreationnogo rajonirovanija [Teoretical basis of the recreaion zoning] // Teoreticheskije osnovy recreationnoy geographii: sb.statej. M.: Institute Geographii RAN, 80-90. (in Russian).

Murtuzalieva, T., Shishkin, A. \& Pogorilyak, B. (2018). Tourism Leadership in Russia: Regional Capacity Estimation. In: Strielkowski W., Chigisheva O. (eds) Leadership for the Future Sustainable Development of Business and Education. Springer Proceedings in Business and Economics. Springer, Cham pp. 617-630 https://doi.org/10.1007/978-3-319-74216-8 61

Pogodina, V. \& Matveevskaya, A. (2017). Geography of Tourism of the European Part of Russia. In: Widawski K., Wyrzykowski J. (eds) The Geography of Tourism of Central and Eastern European Countries. Springer, Cham. https://doi.org/10.1007/978-3-319-42205-3_10

Preobrazhensky, V.S. (1975). Teoreticheskie osnovy recreazionnoy geographii [Theoretical foundations of recreational geography], M. Nauka, 224 pp. (in Russian).

Pshtyka, V. \& Tolkach, D. (2014). Russia, tourism. In: Jafari J., Xiao H. (eds) Encyclopedia of Tourism. Springer, Cham. https://doi.org/10.1007/978-3-319-01669-6_428-1

Rogach, O.V., Frolova, E.V., Ryabova, T.M., Morozova, L.S., \& Litvinova, E.V. (2020). Management of potential tourist development of municipalities in Russia. International Journal of Advanced and Applied Sciences, 7(8), 43-52. https://doi.org/10.21833/ijaas.2020.08.006

Shomanova, Z.K., Safarov, R.Z., Tleulesov, A.K., Nosenko, Yu.G., Zhumakanova, A.S., \& Larichkin, V.V. (2017). Study of composition of waste from metallurgy production aimed in use them as active phases of catalysts for hydrocarbon raw materials refining, News of the National Academy of Sciences of the Republic of Kazakhstan, Series of Geology and Technical Sciences, 2017, 6(426), c. 195-200

Spiriajevas, E. (2019). Borderlands of Lithuania and Kaliningrad region of Russia: Preconditions for comparative geographic approach and spatial interaction. Springer Geography, 15-29. https://doi.org/10.1007/978-3-319-99392-8_2

Stepanova, S.V., \& Shlapeko, E.A. (2018). Trends in the development of cross-border trade in the Russian-Finnish borderlands. Baltic Region, 10 (4), 103117. https://doi.org/10.5922/2079-8555-2018-4-7

Suleimenov, I., Egemberdieva, Z., Bakirov, A., Baipakbayeva, S., Kopishev, E., \& Mun, G. (2020). Efficiency Problem of renewable energetics systems in the context of a «smart house» concept. E3S Web of Conferences, Volume 164, 5 May 2020.

Vedenin, Yu.A. (1982). Dinamika territorialnyh recreazionnyh system [Dinamic of the recreation systems]. M.: Nauka, $190 \mathrm{pp}$. (in Russian).

Widawski, K.., \& Wyrzykowski, J. (2017). The Geography of Tourism of Central and Eastern European Countries, Springer. https://doi.org/10.1007/978-3-319-42205-3

Zorin, I.V. (1969). Economiko-geographicheskie factory formirovanija recreazionnyh rajonov [Economic and geographic factors of formation the recreational regions] In: Geographicheskie problemy formirovanija otdyha I turizma: tezisy docladov. M.: Vsesojus. Geogr. Obshestvo, 29-37. (in Russian).

*** Eurostat (2019). Number of establishments, bedrooms and bed-places. https://ec.europa.eu/eurostat/databrowser/view/tin00181/default/table?lang=en accessed 20.06.2020

*** Ministry of culture of the Russian Federation (2020). Rating subyektov Rossijskoy Federazii po razvitiju turizma [Rating of subjects of the Russian Federation for tourism development]. https://www.mkrf.ru/press/news/reyting-subektov-rossiyskoy-federatsii-po-razvitiyu20171006160552/ accessed 20.06.2020.

*** Rosstat. (2019a). Chislo kollektivnyh sredstv razmezhenija [Number of accommodation establishments] https://fedstat.ru/indicator/31579, accessed 20.06.2020. (in Russian)

*** Rosstat (2019b). Chislo mest v kollektivnyh sredstvah razmezhenija [Number of bed-places in accommodation establishments] https://fedstat.ru/indicator/ 31579 , accessed 20.06.2020. (in Russian).

*** Rosstat. (2019d). Chislennost inostrannyh grazdan, razmechennyh $v$ kollektivnyh sredstvah razmezhenija; [Number of foreigners placed in accommodation establishments]. URL: https://fedstat.ru/indicator/44042, accessed 20.06.2020. (in Russian).

*** Rosstat. (2019e). Chislo vyezdnyh touristicheskih poezdok [Number of outbound tourist trips]. https://www.gks.ru/free_doc/new_site/business/torg/ tur/tab-tur1-2.htm accessed 20.06.2020. (in Russian).

*** Rosstat. (2019c). Chislennost grazhdan RF, razmechennyh v kollektivnyh sredstvah razmezhenija; [Number of Russian citizens placed in accommodation establishments]. https://fedstat.ru/indicator/44040, accessed 20.06.2020. (in Russian).

*** Strategija razvitija turizma v Rossijskoy Federazii do 2035 (2019) [Strategy of tourism development in Russian Federation till 2035]. http://government.ru/docs/37906/ accessed 20.06.2020. (in Russian).

*** World Data Atlas (2019). International tourism, number of departures // knoema. World Data Atlas https://knoema.com/atlas/topics/Tourism/KeyTourism-Indicators/Number-of-departures accessed 20.06.2020. 